\title{
Morphological and Molecular Analyses of Rheophytic Rhododendron ripense and Its Allied Dryland Species R. macrosepalum (Ericaceae)
}

\author{
Nanako Yokoyama, Hiroshi Hayakawa, Kanako Matsuyama, Miwako MuroI, \\ Kyohei Ohga, Katsura Ito, Ryo Arakawa and Tatsuya FuKuda \\ Graduate School of Integrated Arts and Sciences, Kochi University, \\ Monobe, Nankoku, Kochi 783-8502, Japan
}

(Received January 19, 2012; Accepted July 2, 2012)

\begin{abstract}
The areas along rivers and streams are composed of particular environmental characteristics, and plants growing within this environment, called rheophytes, are subjected to flash floods after heavy rainfall as a strong selective pressure. To identify potential hybridization of the rheophytic Rhododendron ripense Makino and its allied dryland species $R$. macrosepalum Maxim., we conducted morphological and molecular analyses of these plant species. These analyses revealed a high rate of hybridization and introgression from $R$. ripense into $R$. macrosepalum, suggesting that hybrid plants arising from $R$. ripense and $R$. macrosepalum may develop broader leaves than $R$. ripense and may affect the flooding of river waters along the riverside.
\end{abstract}

Keywords : hybridization, phytochrome, rheophyte, Rhododendron

\section{INTRODUCTION}

Interspecific hybrids are very useful materials to introduce new genetic divergence from wild species into crops and horticultural species, and have been used for many horticultural and ornamental plants (Allard, 1960). The genus Rhododendron belongs to the family Ericaceae and contains many horticultural species, and most of which are hybrids that are propagated from cuttings or graftings. In fact, the hybrids of Rhododendron are immensely varied in color, size, shape and winter hardiness as a result of their complex genetic background. Plants can react to changes in their environment with a variety of short-term physiological and morphological responses, which occur within a framework of adaptations fashioned by natural selection and species diversity. Of the various environments, environments containing riparian vegetation are temporally and spatially heterogeneous as a result of fluvial disturbances and comprise numerous different habitat types, including channels, channel banks, floodplains, and wetland habitats. Riparian plant species exhibit a diversity of morphological adaptations, which enable them to persist in these variable and dynamic habitats. Among them, plant species in areas that sustain flash floods, known as rheophytes (van Steenis, 1981), have narrow leaves to adapt to the flow of river water (Kato and Imaichi, 1992; Imaichi and Kato, 1992). Rhododendron ripense Makino is a rheophytic species and semievergreen shrub endemic to Japan that is distributed in western Honshu, Shikoku, and northeastern Kyushu (Yamazaki, 1993). This species has brancelets and petioles with spreading glandular

Corresponding author: Tatsuya Fukuda, fax: +81-88-864-5140, e-mail : tfukuda@kochi-u.ac.jp 


\section{N. YOKOYAMA ET AL.}

pilose hairs, densely mixed with ascending eglandular strigose hairs (Yamazaki, 1993). Recently, a comparative morphological and anatomical study of this species and its closely related dryland species ( $R$. macrosepalum Maxim.) indicated that $R$. Ripense (approx. $35.0 \mathrm{~cm}$ width) had narrower leaves than $R$. macrosepalum (approx. $55.3 \mathrm{~cm}$ width), and this stenophyllization in $R$. ripense appeared to be caused by a decrease in the number of cells found in the leaf-width direction (Ueda et al., 2012). These species could be distinguished with their leaf width, and there is a strong correlation between gross morphology and anatomy in leaves (Ueda et al., 2012).

In general, geographic and habitat isolation are among the most important factors responsible for establishing the level of reproductive segregation that leads to measurable genetic differentiation (Coyne and Orr, 2004). Moreover, since dispersal of individuals and gametes is generally more likely among geographically close demes, landscape discontinuities and distributional gaps result in increased neutral divergence (Devaux and Lande, 2008). Normally, the distributions of $R$. ripense (in western Japan) and $R$. macrosepalum (in eastern Japan) do not overlap; however, these distributions do overlap in some localities in the eastern Shikoku and Chugoku districts. Even though the habitats in which these species grow are different (riverside for $R$. ripense and forest for $R$. macrosepalum), the distance between populations of $R$. ripense and $R$. macrosepalum is very short in some areas, suggesting that there may be a natural hybridization between the species. Two other species, $R$. $x$ hortense Nakai and R. x mucronatum (Blume) G. Don, are thought to be putative hybrids or represent a putative hybrid species originating from $R$. ripense and $R$. macrosepalum (Inobe, 1971; Yamazaki and Yamazaki, 1972). Natural hybridization is perceived as an important phenomenon in plant speciation (Arnold, 1997; Rieseberg et al., 2000). In particular, the family Ericaceae, including the genus Rhododendron, comprises many horticulture species via hybridization (Tolstead and Glencoe, 1991; Kehr, 1996; Barlup, 2002; Sakai et al., 2006; Jones et al., 2007).

Various molecular markers have been used to assess the genetic variability of wild plants, and chloroplast and nuclear markers provide information that allows researchers to estimate the putative parents involved in hybridization and introgression (Wendel and Doyle, 1998; Nishizawa and Watano, 2000). Previous studies indicated that polymorphisms in the intergenic region between trn $W$ and trnP in chloroplast DNA (cpDNA) and the phytochrome gene in nuclear DNA (nrDNA) have proven to be effective tools with which to clarify the relationship of closely related taxa (Tsukaya et al., 2003; Samuel et al., 2005; Muleo et al., 2009). Among phytochrome genes, phytochrome $\mathrm{C}$ (Phy $\mathrm{C}$ ) is used to construct phylogenetic tree of various taxa (Mathews and Donoghue, 2000; Samuel et al., 2005; Jabaily and Sytsma, 2010). To examine the rheophyte $R$. ripense, its allied dryland species $R$. macrosepalum, and their interspecific hybridization, we analysed their morphology, the intergenic region between $\operatorname{trn} W$ and $\operatorname{trn} P$ of cpDNA, and the phytochrome C (PhyC) gene of nrDNA using individual plants from specific areas in Shikoku, Japan.

\section{MATERIALS AND METHODS}

\section{Plant materials and morphological analysis}

All $R$. ripense and $R$. macrosepalum samples examined in this study were collected from the field in 2011 (Fig. 1). A total of 82 individuals, representing 8 populations, were sampled from across the range of both species (Tables 1 and 2). In particular, the 2 species could be distinguished by the number of stamen per plant, a qualitative morphological characteristic; $R$. ripense generally has more than 10 stamens, while $R$. macrosepalum has 5 (Yamazaki, 1993). Therefore, the number of stamens was counted for each individual plant.

Molecular analysis

For the molecular analysis, total DNA was isolated from 200 to $300 \mathrm{mg}$ dry weight of leaves using a Plant Genomic DNA Mini Kit (VIOGENE, Sunnyvale, USA), according to the 


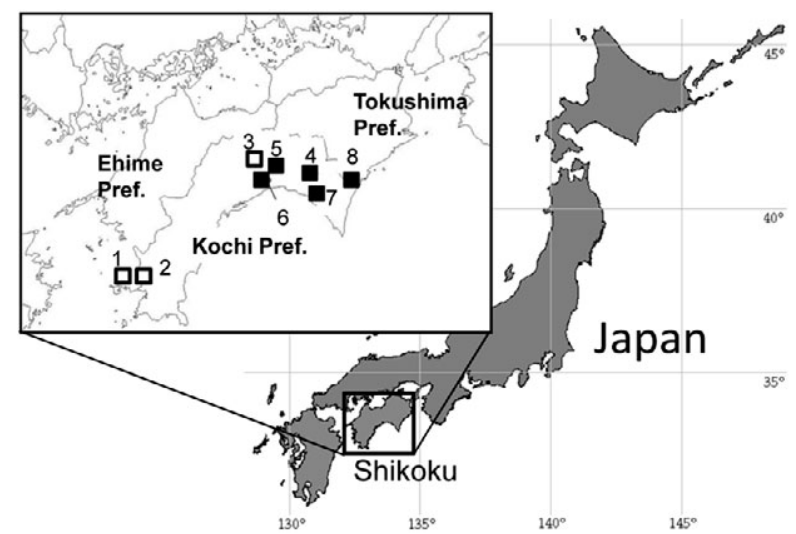

Fig. 1 Sampling localities used in this study. See Table 1 for other abbreviations. $\square$ : Rhododendron ripense; $\mathbf{\square}$ : $R$. macrosepalum.

Table 1 Sampling localities of Rhododendron ripense and $R$. macrosepalum.

\begin{tabular}{|c|c|c|c|c|c|c|}
\hline Species & No. & Locality & Latitude & Longitude & $\begin{array}{l}\text { Sample } \\
\text { nos. }^{z}\end{array}$ & $\begin{array}{l}\text { Individual } \\
\text { number }\end{array}$ \\
\hline \multirow[t]{3}{*}{$R$. ripense } & 1 & $\begin{array}{l}\text { Ehime Prefecture Minamiuwa-Gun, } \\
\text { Ainan-Cho, Souzu River }\end{array}$ & $\mathrm{N} 33^{\circ} 0^{\prime} 31^{\prime \prime}$ & $\mathrm{E} 132^{\circ} 36^{\prime} 24^{\prime \prime}$ & $2-10$ & 8 \\
\hline & 2 & $\begin{array}{l}\text { Kochi Prefecture Sukumo City, } \\
\text { Matsuda Town, Matsuda River }\end{array}$ & $\mathrm{N} 33^{\circ} 3^{\prime} 11^{\prime \prime}$ & $\mathrm{E} 132^{\circ} 41^{\prime} 39^{\prime \prime}$ & $11-28$ & 10 \\
\hline & 3 & $\begin{array}{l}\text { Kochi Prefecture Nagaoka-Gun, } \\
\text { Motoyama-Cho, Asemi River }\end{array}$ & $\mathrm{N} 33^{\circ} 46^{\prime} 51^{\prime \prime}$ & $\mathrm{E} 132^{\circ} 41^{\prime} 39^{\prime \prime}$ & $30-44$ & 10 \\
\hline \multirow[t]{5}{*}{ R. macrosepalum } & 4 & $\begin{array}{l}\text { Kochi Prefecture Aki-Gun, } \\
\text { Umaji Villege, Umaji }\end{array}$ & $\mathrm{N} 33^{\circ} 33^{\prime} 14^{\prime \prime}$ & $\mathrm{E} 134^{\circ} 2^{\prime} 58^{\prime \prime}$ & $\begin{array}{l}134^{-} \\
160\end{array}$ & 16 \\
\hline & 5 & $\begin{array}{l}\text { Kochi Prefecture Kounan City, } \\
\text { Noichi-Cho, Onishi }\end{array}$ & $\mathrm{N} 33^{\circ} 34^{\prime} 15^{\prime \prime}$ & $\mathrm{E} 133^{\circ} 42^{\prime} 12^{\prime \prime}$ & 101 & 1 \\
\hline & 6 & $\begin{array}{l}\text { Kochi Prefecture Kami City, } \\
\text { Kahoku-Cho, Ioroi }\end{array}$ & $\mathrm{N} 33^{\circ} 39^{\prime} 3^{\prime \prime}$ & $\mathrm{E} 133^{\circ} 45^{\prime} 70^{\prime \prime}$ & $\begin{array}{l}105^{-} \\
133\end{array}$ & 23 \\
\hline & 7 & $\begin{array}{l}\text { Kochi Prefecture Aki-Gun, } \\
\text { Yasuda-Cho, Segiri }\end{array}$ & $\mathrm{N} 33^{\circ} 31^{\prime} 19^{\prime \prime}$ & $\mathrm{E} 134^{\circ} 2^{\prime} 00^{\prime \prime}$ & $\begin{array}{l}102^{-} \\
104\end{array}$ & 3 \\
\hline & 8 & $\begin{array}{l}\text { Tokusima Prefecture Kaiyo-Gun, } \\
\text { Kaiyo-Cho, Hirai }\end{array}$ & $\mathrm{N} 33^{\circ} 41^{\prime} 21^{\prime \prime}$ & $\mathrm{E} 134^{\circ} 16^{\prime} 15^{\prime \prime}$ & $\begin{array}{l}163^{-} \\
180\end{array}$ & 11 \\
\hline
\end{tabular}

${ }^{2}$ Sample nos. correspand to Table 2 .

manufacturer's protocol. We amplified the intergenic region between $t r n W$ and $t r n P$ from cpDNA and the PhyC gene from nrDNA with primers designed by Nishizawa and Watano (2000) and Samuel et al. (2005), respectively. Isolated DNA was amplified by PCR in a $50 \mu \mathrm{L}$ reaction volume containing approximately $50 \mathrm{ng}$ total DNA, $10 \mathrm{mM}$ Tris- $\mathrm{HCl}$ buffer ( $\mathrm{pH} 8.3$ ), $50 \mathrm{mM} \mathrm{KCl}, 1.5$ $\mathrm{mM} \mathrm{MgCl} 2,0.2 \mathrm{mM}$ of each dNTP, 1.25 units Taq DNA polymerase (Takara), and $0.5 \mu \mathrm{M}$ of each primer. We used the following thermal cycle profile for amplification: $1.5 \mathrm{~min}$ at $94^{\circ} \mathrm{C}, 2 \mathrm{~min}$ at $48^{\circ} \mathrm{C}$, and $3 \mathrm{~min}$ at $72^{\circ} \mathrm{C}$ for 45 cycles, followed by a 15 -min final extension at $72^{\circ} \mathrm{C}$. After amplification, PCR products representing the intergenic region between $\operatorname{trn} W$ and $\operatorname{trn} P$ and those corresponding to the $P h y \mathrm{C}$ gene were subjected to electrophoresis on $1.0 \%$ low-melting-temperature agarose gels to remove by-products and purify the amplified products. We sequenced the purified PCR products using a BigDye Terminator v. 3.1 Cycle Sequencing Kit (Applied BioSystems) and an ABI Prism 3100 Genetic Analyzer (Applied BioSystems) according to the manufacturer's instructions. 
N. YOKOYAMA ET AL.

Table 2 Morphological and molecular data for individuals collected at in Kochi Prefecture, Shikoku, Japan.

\begin{tabular}{|c|c|c|c|c|c|c|c|}
\hline Individual no. & Morphology & cp trnW-P & PhyC & Individual no. & Morphology & cp $t r n W-P$ & Phy C \\
\hline 2 & $\mathrm{R} / \mathrm{M}$ & $\mathrm{R}$ & $\mathrm{R}$ & 116 & $\mathrm{R} / \mathrm{M}$ & $\mathrm{M}$ & $\mathrm{R} / \mathrm{M}$ \\
\hline 3 & $\mathrm{R} / \mathrm{M}$ & $\mathrm{R}$ & $\mathrm{R}$ & 117 & $\mathrm{M}$ & M & $\mathrm{R} / \mathrm{M}$ \\
\hline 4 & $\mathrm{R}$ & $\mathrm{R}$ & $\mathrm{R}$ & 118 & M & M & $\mathrm{R}$ \\
\hline 5 & $\mathrm{R}$ & $\mathrm{R}$ & $\mathrm{R}$ & 119 & M & M & $\mathrm{R} / \mathrm{M}$ \\
\hline 6 & $\mathrm{R}$ & $\mathrm{R}$ & $\mathrm{R}$ & 121 & M & M & $\mathrm{R}$ \\
\hline 8 & $\mathrm{R}$ & $\mathrm{R}$ & $\mathrm{R}$ & 123 & M & M & $\mathrm{R}$ \\
\hline 9 & $\mathrm{R}$ & $\mathrm{R}$ & $\mathrm{R}$ & 125 & M & M & $\mathrm{R}$ \\
\hline 10 & $\mathrm{R}$ & $\mathrm{R}$ & $\mathrm{R}$ & 126 & $\mathrm{R} / \mathrm{M}$ & M & $\mathrm{R} / \mathrm{M}$ \\
\hline 11 & $\mathrm{R}$ & $\mathrm{R}$ & $\mathrm{R}$ & 127 & $\mathrm{R} / \mathrm{M}$ & M & $\mathrm{R} / \mathrm{M}$ \\
\hline 12 & $\mathrm{R}$ & $\mathrm{R}$ & $\mathrm{R}$ & 128 & $\mathrm{R} / \mathrm{M}$ & M & $\mathrm{R} / \mathrm{M}$ \\
\hline 13 & $\mathrm{R}$ & $\mathrm{R}$ & $\mathrm{R}$ & 130 & $\mathrm{M}$ & M & $\mathrm{R} / \mathrm{M}$ \\
\hline 14 & $\mathrm{R}$ & $\mathrm{R}$ & $\mathrm{R}$ & 131 & M & M & $\mathrm{R} / \mathrm{M}$ \\
\hline 15 & $\mathrm{R}$ & $\mathrm{R}$ & $\mathrm{R}$ & 133 & M & M & $\mathrm{R}$ \\
\hline 16 & $\mathrm{R}$ & $\mathrm{R}$ & $\mathrm{R}$ & 134 & M & M & $\mathrm{R} / \mathrm{M}$ \\
\hline 17 & $\mathrm{R}$ & $\mathrm{R}$ & $\mathrm{R}$ & 138 & M & $\mathrm{M}$ & $\mathrm{R}$ \\
\hline 19 & $\mathrm{R} / \mathrm{M}$ & $\mathrm{R}$ & $\mathrm{R}$ & 139 & M & $\mathrm{M}$ & $\mathrm{R}$ \\
\hline 20 & $\mathrm{R}$ & $\mathrm{R}$ & $\mathrm{R}$ & 141 & M & M & $\mathrm{R}$ \\
\hline 28 & $\mathrm{R}$ & $\mathrm{R}$ & $\mathrm{M}$ & 143 & $\mathrm{R} / \mathrm{M}$ & M & $\mathrm{M}$ \\
\hline 30 & $\mathrm{R}$ & $\mathrm{R}$ & $\mathrm{R}$ & 144 & $\mathrm{R} / \mathrm{M}$ & $\mathrm{M}$ & $\mathrm{R}$ \\
\hline 31 & $\mathrm{R}$ & $\mathrm{R}$ & $\mathrm{R}$ & 145 & $\mathrm{M}$ & $\mathrm{M}$ & $\mathrm{R}$ \\
\hline 33 & $\mathrm{R}$ & $\mathrm{R}$ & $\mathrm{R}$ & 146 & $\mathrm{R} / \mathrm{M}$ & $\mathrm{M}$ & $\mathrm{R} / \mathrm{M}$ \\
\hline 34 & $\mathrm{R}$ & $\mathrm{R}$ & $\mathrm{R}$ & 148 & $\mathrm{M}$ & M & $\mathrm{R} / \mathrm{M}$ \\
\hline 35 & $\mathrm{R} / \mathrm{M}$ & $\mathrm{R}$ & $\mathrm{R}$ & 149 & M & $\mathrm{M}$ & $\mathrm{R}$ \\
\hline 36 & $\mathrm{R} / \mathrm{M}$ & $\mathrm{R}$ & $\mathrm{R}$ & 150 & $\mathrm{R} / \mathrm{M}$ & $\mathrm{M}$ & $\mathrm{R} / \mathrm{M}$ \\
\hline 37 & $\mathrm{R}$ & $\mathrm{R}$ & $\mathrm{R}$ & 155 & $\mathrm{R} / \mathrm{M}$ & M & $\mathrm{R}$ \\
\hline 39 & $\mathrm{R}$ & $\mathrm{R}$ & $\mathrm{R}$ & 157 & $\mathrm{R} / \mathrm{M}$ & M & $\mathrm{R} / \mathrm{M}$ \\
\hline 41 & $\mathrm{R}$ & $\mathrm{R}$ & $\mathrm{R}$ & 158 & $\mathrm{M}$ & M & $\mathrm{R} / \mathrm{M}$ \\
\hline 44 & $\mathrm{R}$ & $\mathrm{R}$ & $\mathrm{R}$ & 159 & $\mathrm{R} / \mathrm{M}$ & $\mathrm{M}$ & $\mathrm{R} / \mathrm{M}$ \\
\hline 101 & M & M & $\mathrm{R}$ & 160 & M & M & $\mathrm{R}$ \\
\hline 102 & M & M & $\mathrm{M}$ & 163 & M & $\mathrm{M}$ & $\mathrm{R}$ \\
\hline 103 & M & M & $\mathrm{M}$ & 164 & M & $\mathrm{M}$ & $\mathrm{R} / \mathrm{M}$ \\
\hline 104 & $\mathrm{R} / \mathrm{M}$ & M & $\mathrm{R} / \mathrm{M}$ & 166 & M & $\mathrm{M}$ & $\mathrm{R} / \mathrm{M}$ \\
\hline 105 & $\mathrm{R} / \mathrm{M}$ & M & $\mathrm{R}$ & 168 & M & $\mathrm{M}$ & $\mathrm{R} / \mathrm{M}$ \\
\hline 107 & $\mathrm{M}$ & M & $\mathrm{R} / \mathrm{M}$ & 172 & M & $\mathrm{M}$ & $\mathrm{M}$ \\
\hline 108 & $\mathrm{R} / \mathrm{M}$ & M & $\mathrm{M}$ & 174 & M & $\mathrm{M}$ & $\mathrm{M}$ \\
\hline 109 & M & M & $\mathrm{R}$ & 175 & $\mathrm{R} / \mathrm{M}$ & M & $\mathrm{R}$ \\
\hline 110 & M & M & $\mathrm{R}$ & 176 & $\mathrm{R} / \mathrm{M}$ & $\mathrm{M}$ & $\mathrm{R} / \mathrm{M}$ \\
\hline 111 & M & M & $\mathrm{M}$ & 177 & $\mathrm{M}$ & M & $\mathrm{R}$ \\
\hline 112 & M & M & $\mathrm{R}$ & 179 & M & M & $\mathrm{R} / \mathrm{M}$ \\
\hline 113 & M & M & $\mathrm{R}$ & 180 & M & M & $\mathrm{R} / \mathrm{M}$ \\
\hline 114 & M & M & $\mathrm{M}$ & & & & \\
\hline 115 & M & M & $\mathrm{R}$ & & & & \\
\hline
\end{tabular}

$\mathrm{R}, \mathrm{M}$, and R/M indicate Rhododendron ripense, $R$. macrosepalum, and heterozygous for $R$. ripense and $R$. macrosepalum, respectively, in each column.

\section{RESULTS AND DISCUSSION}

In this study, we recorded more than 10 stamens in $R$. ripense plants and 5 stamens in $R$. macrosepalum plants. We observed 21 intermediate types. With regards to the intergenic region between trnW and trnP from cpDNA, the length was $254 \mathrm{bp}$ in both $R$. ripense and $R$. Macrosepalum (accession nos. AB692784, AB692785). The cpDNA sequences differed from each other by 2 nucleotide substitutions (Fig. 2) and were in accordance with the morphological identification conducted using stamen numbers. We found apparent difference in the cpDNA sequences 


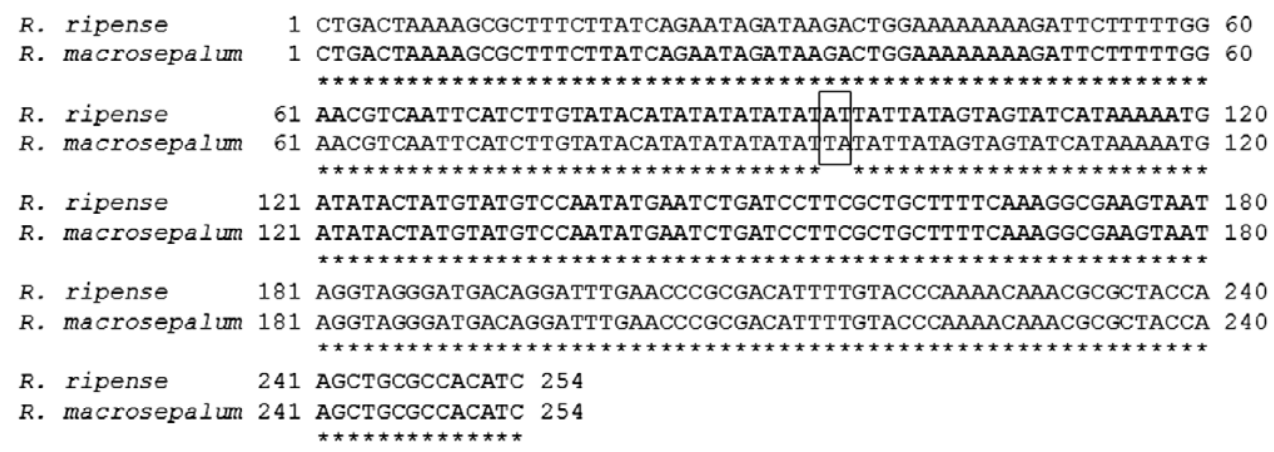

Fig. 2 Comparison of the intergenic sequences found between $\operatorname{trn} W$ and $\operatorname{trn} P$ (cpDNA) in Rhododendron ripense and $R$. macrosepalum. Mutation and nonmutation sites are shown in the box and asterisks, respectively.

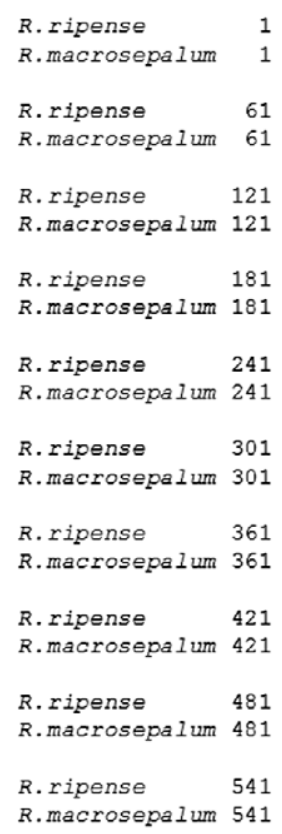

TAGAAT GATATGTGATTGTTTGGCCCCTCCAGTTAGGGTTATTCAAGACAAGAGATTTGA TAGAATGATATGTGATTGTTTGGCCCCTCCAGTTAGGGTTATTCAAGACAAGAGATTTGA

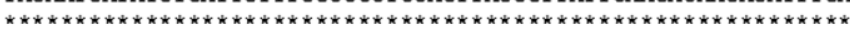
TGAACCATTGAGTCTTGGTGGATCCACATTAAGGTCTCCTCATGGGTGTCATGCTCAGTA TGAACCATTGAGTCTTGGTGGATCCACATTAAGGTCTCCTCATGGGTGTCATGCTCAGTA $* * * * * * * * * * * * * * * * * * * * * * * * * * * * * * * * * * * * * * * * * * * * * * * * * * * * * * * * * * * *$ CATGGCGAATATGGGGTCCATTGCATCTCTTGTGTTATCCGTCACAATCAACAAGGAAGA CATGGCGAATATGGGGTCCATTGCATCTCTTGTGTTATCCGTCACAATCAACAAGGAAGA

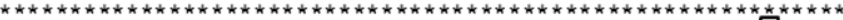
CCAGGAGTCAGAGAGTGATCCACAAAGGGGAAGAAAACT GTGGGGTTTGGTTGT PITTA CCAGGAGTCAGAGAGTGATCCACAAAGGGGAAGAAAACTGTGGGGTTTGGTTGICIFTCA $* * * * * * * * * * * * * * * * * * * * * * * * * * * * * * * * * * * * * * * * * * * * * * * * * * * * * * * * * * * *$ TCACACGAGCCCTAGGTTTGTTCCGTTTCCCTTGAGGTACGCGTGT GAGTTCTTAGTTCA TCACACGAGCCCTAGGTTT GTTCCGTTTCCCTTGAGGTACGCGTGT GAGTTCTTAGTTCA $* * * * * * * * * * * * * * * * * * * * * * * * * * * * * * * * * * * * * * * * * * * * * * * * * * * * * * * * * * * * * * * * *$ AGTTTTTGGTGTTCAGATTTACAAGGAAGTAGAGATGGCGGTTCAACTGAGGGAGAAGCA AGTTTTTGGTGTTCAGATTTACAAGGAAGTAGAGATGGCGGTCAACTGAGGGAGAAGCA A TATTTTGCGGACTCAAGCAGTGCTTTGTGACATGCTCCTAAGAGATGCTCCCGTTGGAAT TATTTTGCGGACTCAAGCAGTGCTTTGTGACATGCTCCTAAGAGATGCTCCCGTTGGAAT

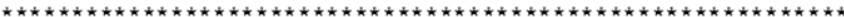
TATCAATCAATCACCAAACGTGATGGATCTTGTCAATTGTGATGGAGCTGCAATTTATTA TATCAATCAATCACCAAACGTGATGGATCTTGTCAATTGTGATGGAGCTGCAATTTATTA $* * * * * * * * * * * * * * * * * * * * * * * * * * * * * * * * * * * * * * * * * * * * * * * * * * * * * * * * * * * *$ CAGGAACAAAGTTTGGTCTCTTGGGATCACCCCTTCAGAGGCACAAATCAGAGATATAGC CAGGAACAAAGTTTGGTCTCTTGGGATCACCCCTTCAGAGGCACAAATCAGAGATATAGC * CGAATGGCTTATTGAGTACCACGGGGGGAGTACAGGGTTAAGTACTGATAGCCTTATGGAA 601 CGA.ATGGCTTATTGAGTACCACGGGGGAGTACAGGTTAAGTACTGATAGCCTTATGGAA 601

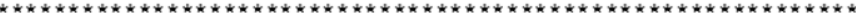

Fig. 3 Comparison of the PhyC gene sequences (nrDNA) of Rhododendron ripense and R. macrosepalum. Mutation and nonmutation sites are shown in the box and asterisks, respectively.

between the $R$. ripense-type (R-type) and R. macrosepalum-type (M-type) plants (Table 2).

The length of the PhyC gene from nrDNA was $601 \mathrm{bp}$ in both $R$. ripense and $R$. macrosepalum (Fig. 3: accession nos. AB692782, AB692783). We found 2 alleles in the PhyC sequence. All 37 R. ripense individuals, with the exception of sample number 28, had a PhyC allele, which we designated the R-type (Table 2). We also found another PhyC sequence, which differed from the R-type sequence by a single nucleotide substitution (Fig. 3). This sequence was mainly found in $R$. macrosepalum individuals in this study, and therefore, we named this sequence after the M-type PhyC sequence. One individual $R$. ripense plant and $8 R$. macrosepalum plants were homozygous for the M-type Phy $\mathrm{C}$ sequence (Table 2). In addition, 23 individual $R$. macrosepalum plants had both R- and M-type PhyC sequences. The heterozygous type appeared to be a hybrid 
between R-type and M-type sequences in the PhyC gene from nrDNA. These sequences have been deposited in the DDBJ/EMBL/GenBank International DNA databases (Table 3).

Hybridization can arise from unidirectional gene flow from one species to another or through bidirectional gene flow with both species serving as maternal and paternal parents. The direction of gene movement has important implications in our understanding of the evolutionary potential and sustainability of hybrid progenies. Contrasts between maternally inherited cpDNA and nrDNA inherited through both parents can provide confirmation of hybridization and evidence for the direction of gene flow (Rieseberg et al., 1990; Rieseberg and Ellstrand, 1993; Martinsen et al., 2001; Wu and Campbell, 2005; Wallace, 2006). For example, both parents contributed to the cytoplasmic diversity of the hybrid sunflower Helianthus deserticola, leading to high levels of differentiation among the population (Gross et al., 2003). The polyploid Tragopogon complex, T. miscellus, exhibits different floral morphologies depending on whether T. dubius or T. pratensis is the maternal parent (Tate et al., 2009). In our study, a combination of morphological traits and cpDNA/nrDNA analysis suggested that natural hybridization between $R$. ripense and $R$. macrosepalum occurred in some areas. Interestingly, all hybrids between the 2 species had M-type cpDNA sequences, and putative introgression was found in $R$. ripense, where sample No. 28 was found to have both R-type cpDNA and M-type nrDNA (Table 2). This result indicated that asymmetric hybridization could occur from $R$. ripense into $R$. macrosepalum. Some studies of natural hybrids have demonstrated asymmetric hybridization (Wolfe and Elisens, 1995; Buggs and Pannell, 2006; Hamzeh et al., 2007), suggesting that this phenomenon is common in natural systems (Currat et al., 2008). Asymmetric hybridization is much stronger in organelle genes than nuclear genes because the former experience lower rates of gene flow due to uniparental inheritance, and selection is a common explanation for asymmetric patterns of introgression (Lehman et al., 1991; Borge et al., 2005). For example, selection for pollen characteristics, such as large quantities of pollen production, gametic compatibility, and dispersal methods, could result in preferential gene flow to a species with lower pollen production or a less-effective means of pollen dispersal. In fact, Currat et al. (2008) found strong evidence of asymmetrical introgression in a wide variety of taxa. Our results describing asymmetrical introgression indicated that there were very few hybrids that were formed by the movement of $R$. macrosepalum genes into $R$. Ripense.

In summary, we demonstrated interspecific hybridization between rheophytic $R$. ripense and its allied dryland species $R$. macrosepalum by analyzing the combined morphological, cpDNA, and nrDNA data. The results, based on molecular information, provide an unbiased interpretation of hybridization. It will be interesting to see whether a more comprehensive sampling and additional genetic evidence will support the working hypothesis developed in this study. A molecular basis for further studies of $R$. ripense and $R$. macrosepalum plants has been established.

We wish to thank Drs. J. Yokoyama, O. Miura, R. Ueda, Y. Tsuchiya, Y. Yoshimi, S. Isomoto, H. Miyata, Y. Kumekawa, N. Kakimoto, S. Takei, and T. Sunami for providing much help. This study was partly supported by the River Fund in charge of the Foundation of River and Watershed Environment Management (FOREM), Japan (to T. Fukuda).

\section{REFERENCES}

Allard, R. W. 1960. Principles of plant breeding, John Wiley \& Sons, Inc., New York, p 1-264.

Arnold, M. L. 1997. Natural hybridization and evolution, Oxford University Press, New York, NY, p 1-232.

Barlup, J. 2002. Let's talk hybridizing: Hybridizing with elepidote polyploid rhododendrons. J. Am. Rhod. Soc. 76: 75-77.

Borge, T., Lindroos, K., Nadvornik, P., Syvanen, A. C., Saetre, G. P. 2005. Amount of introgression in 
flycatcher hybrid zones reflects regional differences in pre and post-zygotic barriers to gene exchange. J. Evolution Biol. 18: 1416-1424.

Buggs, R. J. A., Pannell, J. R. 2006. Rapid displacement of a monoecious plant lineage is due to pollen swamping by a dioecious relative. Curr. Biol. 16: 996-1000.

Coyne, J. A., Orr, H. A. 2004. Speciation. Sinauer Associates, Sunderland, Massachusetts, p 1-545.

Currat, M., Ruedi, M., Petit, R. J., Excoffier, L. 2008. The hidden side of invasions: massive introgression by local genes. Evolution 62: 1908-1920.

Devaux, C., Lande, R. 2008. Incipient allochronic speciation due to non-selective assortative mating by flowering time, mutation and genetic drift. Proc. R. Soc. Lond. B. 275: 2723-2732.

Gross, B. L., Schwarzbach, A. E., Rieseberg, L. H. 2003. Origin (s) of the diploid hybrid species Helianthus deserticola (Asteraceae). Am. J. Bot. 90: 1708-1719.

Hamzeh, M., Sawchyn, C., Perinet, P., Dayanandan, S. 2007. Asymmetrical natural hybridization between Populus deltoides and P. balsamifera (Salicaceae). Can. J. Bot. 85: 1227-1232.

Imaichi, R., Kato, M. 1992. Comparative leaf development of Osmunda lancea and O. japonica (Osmundaceae): heterochronic origin of rheophytic stenophylly. Bot. Mag. Tokyo 105: 199-213.

Inobe, T. 1971. A study of the autogenesis of Rhododendron hortense Nakai. (in Japanese) J. Jpn. Bot. 46: 311-315.

Jabaily, R. S., Sytsma, K. J. 2010. Phylogenetics of Puya (Bromeliaceae): Placement, major lineages, and evolution of Chilean species. Am. J. Bot. 97: 337-356.

Jones, J. R., Ranney, T. G., Lynch, N. P., Krebs, S. L. 2007. Ploidy levels and relative genome sizes of diverse species, hybrids, and cultivars of rhododendron. J. Am. Rhododendron Soc. 61: 220-227.

Kato, M., Imaichi, R. 1992. Leaf anatomy of tropical fern rheophytes with its evolutionary and ecological implications. Can. J. Bot. 70: 165-174.

Kehr, A. E. 1996. Polyploids in rhododendron breeding. J. Am. Rhod. Soc. 50: 215-217.

Lehman, N., Eisenhawer, A., Hansen, K., Mech, L. D., Peterson, R. O., Wayne, R. K. 1991. Introgression of coyote mitochondrial DNA into sympatric North American gray wolf populations. Evolution 45: 104119.

Martinsen, G. D., Whitham, T. G., Turek, R. J., Keim, P. 2001. Hybrid populations selectively filter gene introgression between species. Evolution 55: 1325-1335.

Mathews, S., Donoghue, M. J. 2000. Basal angiosperm phylogeny inferred from duplicate phytochromes a and c. Int. J. Plant Sci. 161: S41-S55.

Muleo, R., Colao, M. C., Miano, D., Cirilli, M., Intrieri, M. C., Baldoni, L., Rugin, E. 2009. Mutation scanning and genotyping by high-resolution DNA melting analysis in olive germplasm. Genome 52: 252-260.

Nishizawa, T., Watano, Y. 2000. Primer pairs suitable for PCR-SSCP analysis of chloroplast DNA in angiosperms. J. Phytogeogr. Taxon 48: 63-66.

Rieseberg, L. H., Beckstrom-Sternberg, S., Doan, K. 1990. Helianthus annuus ssp. texanus has chloroplast DNA and nuclear ribosomal genes of Helianthus debilis ssp. cucumerifolius. Proc. Natl. Acad. Sci. USA 87: 593-597.

Rieseberg, L. H., Ellstrand, N. C. 1993. What can molecular and morphological markers tell us about plant hybridization? CRC Cr. Rev. Plant Sci. 12: 213-241.

Rieseberg, L. H., Baird, S. J., Gardner, K. A. 2000. Hybridization, introgression, and linkage evolution. Plant Mol. Biol. 42: 205-224.

Sakai, K., Ozaki, Y., Hiramatsu, M., Wakana, A., Okubo, H. 2006. Intrasubgeneric and interploid cross compatibility in evergreen and deciduous azaleas. J. Fac. Agri. Kyushu Univ. 51: 73-81.

Samuel, R., Kathriarachchi, H., Hoffmann, P., Barfuss, M. H. J., Wurdack, K. J., Davis. C. C., Chase. M. W. 2005. Molecular phylogenetics of phyllanthaceae: Evidence from plastid matK and nuclear PHYC sequences. Am. J. Bot. 95: 132-141.

Tate, J. A., Symonds, V. V., Doust, A. N., Buggs, R. J. A., Mavrodiev, E., Majure, L. C., Soltis, P. S., Soltis, D. E. 2009. Synthetic polyploids of Tragopogon miscellus and T. mirus (Asteraceae): 60 years after Ownbey's discovery. Am. J. Bot. 96: 979-988.

Tolstead, W. L., Glencoe, J. F. 1991. Winter-hardy tetraploids of Rhododendron carolinianum and Rhododendron racemosum and their tetraploid hybrids. J. Am. Rhod. Soc. 45: 83-84.

Tsukaya, H., Fukuda, T., Yokoyama, J. 2003. Hybridization and introgression between Callicarpa japonica and C. mollis (Verbenaceae) in central Japan, as inferred from nuclear and chloroplast DNA sequences. Mol. Ecol. 12: 3003-3011. 
Ueda, R., Minamiya, Y., Hirata, A., Hayakawa, H., Muramatsu, Y., Saito, M., Fukuda, T. 2012. Morphological and anatomical analyses of rheophytic Rhododendron ripense Makino (Ericaceae). Plant Species Biology 27: 233-240.

van Steenis, C. G. G. J. 1981. Rheophyte of the world. Sijthoff and Noordhoff, Alpen aan den Rijn.

Wallace, L. E. 2006. Spatial genetic structure and frequency of interspecific hybridization in Platanthera aquilonis and P. dilatata (Orchidaceae) occurring in sympatry. Am. J. Bot. 93: 1001-1009.

Wendel, J. F., Doyle, J. J. 1998. Phylogenetic incongruence: Window into genome history and molecular evolution. In "Molecular Systematics of Plants II and Sequencing" (ed. by Soltis, D. E., Soltis, P. S., Doyle, J. J.), Kluwer Academic Publishers, p 265-296.

Wolfe, A. D., Elisens, W. J. 1995. Evidence of chloroplast capture and pollen-mediated gene flow in Penstemon sect. Peltanthera (Scrophulariaceae). Syst. Bot. 20: 395-412.

Wu, C. A., Campbell, D. R. 2005. Cytoplasmic and nuclear markers reveal contrasting patterns of spatial genetic structure in a natural Ipomopsis hybrid zone. Mol. Ecol. 14: 781-792.

Yamazaki, T., Yamazaki, F. 1972. The cultivar belonging to Rhododendron mucronatum and R. hortense. (in Japanese) J. Jpn. Bot. 47: 167-170.

Yamazaki, T. 1993. Ericaceae. In "Flora of Japan" (ed. by Iwatsuki, K., Tamazaki, T., Boufford, D. E., Ohba, H.), vol. IIIa, Kodansha, Tokyo, p 6-63. 